\title{
Puppets in the Development of Communicative Competencies in Elementary School Students.
}

Lina Veronica Yanac-Leon, Universidad Cesar Vallejo, Perú, (ORCID: https://orcid.org/00000003-1151-2418)

Juan Mendez Vergaray,Universidad Cesar Vallejo, Perú, (ORCID: https://orcid.org/0000-00017286-0534)

Edward Flores, Universidad Cesar Vallejo, Perú, (ORCID: https://orcid.org/0000-0001-8972-5494)

\begin{abstract}
The objective of this systematic review is to analyze the relationship between the use of puppets in the development of communication skills in children. Methodology: 20 articles obtained from the Scopus, EBSCO, Dialnet, Redalyc databases during the months of January and February of this year were used for the research; the study was carried out using the Prisma methodology; the inclusion criteria were research articles, systematic reviews and quantitative studies that addressed the relationship between puppets and communicative skills, and as exclusion criteria: those that did not collect the necessary data for the study, that is, with methodological deficiencies, or those that were not directly related to the categories. Results: 160 documents, 150 articles and 10 theses were reviewed, and 114 research studies were selected after eliminating duplicates, having been excluded 36 articles and 26 theses that did not respond to the categories and methodology; likewise, the evaluation of 32 full-text articles was determined, of which 32 studies were excluded for not meeting the inclusion criteria; and 11 articles and 9 theses were used in the study. Conclusion: It was found that there is a cause-effect relationship between puppets and communicative competencies, insofar as they favor attention and motivation to communicate children's thoughts, feelings and ideas.
\end{abstract}

Keywords: puppets, communicative competence, students.

\section{Introduction}

In the process of economic and linguistic globalization, communicative competence has become interculturally; even with the guidelines of European organizations, which limited intercultural communicative competence, such as the set of skills that achieve understanding and adaptation to new cultures (González, 2019). In addition, communicative competence comes to be groups of knowledge and acquired skills, which achieve the possibility of emitting and capturing information in an adequate way; For this, the use of common language is required, and it can be used as an instrument for oral and written communication; Therefore, its importance lies in the development of grammatical competence, which allows understanding and clearly expressing an idea and adapting them to a certain context, issuing ideas with coherence and cohesion (GarcíaFernández, 2019).

On the other hand, it is important to point out that communicative competence manages to guarantee effectively and successfully activities to plan, execute and evaluate communication, taking into account some characteristic of different contexts and the participants in it; It is to be in the permanent search for a mutual understanding, where interpersonal relationships are generated in a fluid way, with shared teamwork in responsibilities and to be assertive in solving problems that arise (Hernández et al., 2019).

It is important to highlight that the attention paid to education in Latin America and other countries to carry out actions to develop communication, where students manage to have a base for their integral development and to be inserted in the school stage; Likewise, it is at this age where children begin to use grammatical structures of their mother tongue, they manage to discover that through the word they can be attended to and meet a set of needs. Consequently, in line with this position, it is in the home where children begin to speak and when they enter an educational 
institution, they achieve skills to communicate their thoughts and ideas with their peers and adults (Torres et al., 2018).

In school education, promoting the use of puppets plays an important role as the child finds a mediator that helps him express his imagination and develop skills that make it easier for him to move and speak comfortably; Furthermore, through them they manage to identify and become uninhibited, identifying with the characters that allow them to see themselves totally or partially represented in the puppets; In addition, you can communicate with people of all ages, cultures and languages; On the other hand, it is a resource and a strategy that allows to establish a fluid communication between child-child and child-adult, thus facilitating the relationship that in traditional methodological conditions is difficult to achieve (Mármol, 2019).

The educational process has been a matter of concern since primitive times, where theater, as well as puppets, have had relevant importance, either through religion, society and different cultures; Thus, puppets and theater are an educational tool, especially for students of pre-school age and beginning of schooling; and there are even theories that speak of a magical power and special connection between puppets and children, and how it facilitates the achievement of learning; which indicates that the particular characteristics that puppets possess make them an important resource for the teaching-learning process (Zeinali, 2017).

It is important to reiterate that, in education, puppets are a powerful methodological tool in the development of learning activities, which allows to motivate, entertain and entertain during class; Likewise, it provides the opportunity for the most timid students in the development of oral and creative expression, where the development of imagination and fantasy flows, as well as thoughts and ideas that allow the interpretation of the characters when manipulating a puppet, due to to the impact to develop some ability, aptitude and dexterity, such as: the direction of the imaginary world to the real context, the stimulation of the artistic aptitude of the students, the development of coordination and sense of time, the stimulation of attention, understanding, training in values and increasing self-confidence and personal satisfaction (Pablo, 2018). In the same way, for the puppet it has a multiple application in the children's sphere, whether socially, intellectually, aesthetically, psychomotor; and it becomes a valuable psycho-pedagogical tool, insofar as it manages to contribute to the internalization of the bases on which the personality is established and allow the construction of a pleasant and playful climate, which respects the interests of children and stimulates their needs for action and free expression (Cebrián, 2016).

This systematic review aims to carry out a systematic analysis of the development of communication skills of primary school students using puppets as a resource, in the range 20162020 .

\section{Material and method}

The study is a systematic review of the literature in which the Prism method is used in order to systematize the search information in order to analyze the collected material (Gómez, 2004); Likewise, this research allows for an exhaustive, descriptive and evaluative review of the selected documents using key equations and Boléan connectors, to finally be contextualized (Vera, 2009).

For the literature search, the following equations and the Boléan connectors were used: in Spanish "y", "en" with the title "Títeres en la expresión oral", "Rol de los títeres en la expresión oral", "Competencia comunicativa para el aprendizaje" and in English "and", "or" in the title "Puppets in the development ofcommunicative competencies", "Puppets in oral expression", "Role of puppets in oral expression", "Communicative competence for learning" in the databases. 160 investigations were selected, of which 94 studies belong to Scopus, 43 studies to EBSCO, 12 studies in Scielo, 11 studies in Redalyc,

Likewise, in the search for related literature, the following criteria were taken into account:

Inclusion criteria: Free access articles and theses in the 2016-2020 range related to the use of puppets in communication skills. 
Exclusion criteria: studies that had no direct relationship with the unit of analysis. Excluded articles that do not respond to categories and methodology, articles incomplete context.

Of all the studies reviewed, taking into account the inclusion and exclusion criteria, 20 investigations were selected.

\section{Results}

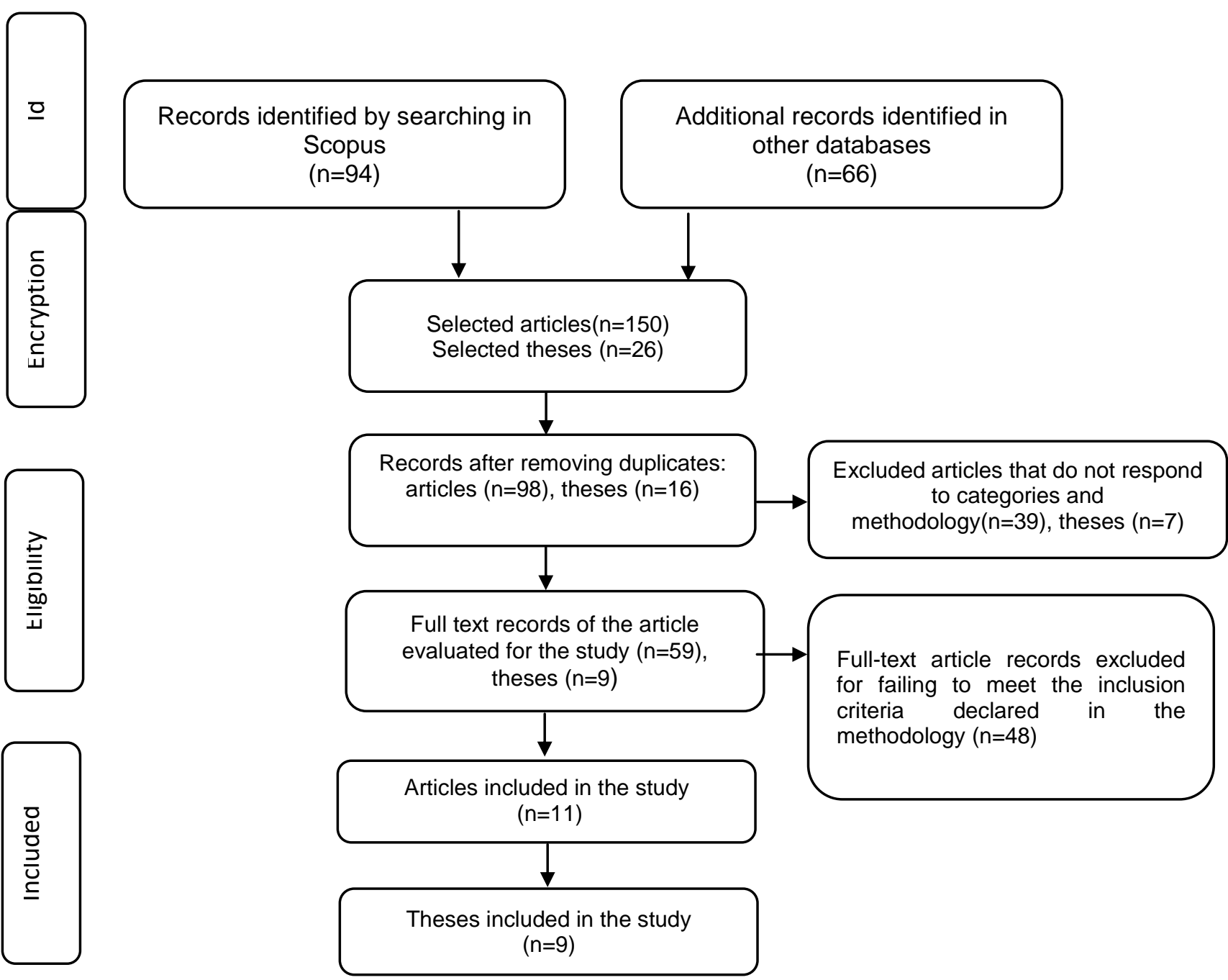

Figure 1. Adaptation of PRISMA Flow Diagram

Of the 160 studies, 150 were articles and 10 theses, and 114 investigations were selected after eliminating duplicates, having excluded 36 articles and 26 theses that did not respond to the categories and methodology; Likewise, the evaluation of 32 full-text articles was determined, of which 32 studies were excluded because they did not meet the inclusion criteria; and 11 articles and 9 theses were used in the study.

\section{Table 1}

Distribution of search results by author (s), category and methodology.

\begin{tabular}{|l|l|c|c|}
\hline & $\begin{array}{c}\text { Puppets in the development of } \\
\text { communication skills in students }\end{array}$ & Methodology \\
\hline
\end{tabular}




\begin{tabular}{|c|c|c|c|c|c|c|c|}
\hline No. & Authors & Puppets & $\begin{array}{c}\text { Communicative } \\
\text { competence }\end{array}$ & Articles & $\begin{array}{c}\text { These } \\
\mathrm{S}\end{array}$ & $\begin{array}{l}\text { Type of } \\
\text { study }\end{array}$ & $\begin{array}{l}\text { Instrument, } \\
\text { technique or } \\
\text { method }\end{array}$ \\
\hline 1 & Tapia y Beltrán (2019) & & $\mathrm{X}$ & $\mathrm{X}$ & & Qualitative & $\begin{array}{l}\text { Interview guide on } \\
\text { communication } \\
\text { skills }\end{array}$ \\
\hline 2 & $\begin{array}{l}\text { Santa Cruz y Montenegro } \\
(2017)\end{array}$ & $\mathrm{X}$ & $\mathrm{X}$ & & $\mathrm{X}$ & Quantitative & $\begin{array}{l}\text { Observation, } \\
\text { observation sheet }\end{array}$ \\
\hline 3 & Delgado, M. (2017) & $\mathrm{X}$ & $\mathrm{X}$ & & $\mathrm{X}$ & Quantitative & $\begin{array}{l}\text { Observation, } \\
\text { observation sheet }\end{array}$ \\
\hline 4 & Yesid y Duarte (2019) & $\mathrm{X}$ & $\mathrm{X}$ & & $\mathrm{X}$ & Quantitative & $\begin{array}{l}\text { Communicative } \\
\text { competence test }\end{array}$ \\
\hline 5 & Olmos (2020) & $\mathrm{X}$ & $\mathrm{X}$ & & $\mathrm{X}$ & Quantitative & $\begin{array}{l}\text { Questionnaires on } \\
\text { puppets and } \\
\text { communication } \\
\text { skills }\end{array}$ \\
\hline 6 & Girotti (2020) & $X$ & & $\mathrm{X}$ & & Qualitative & $\begin{array}{l}\text { Investigation } \\
\text { article }\end{array}$ \\
\hline 7 & $\begin{array}{l}\text { Martínez y Rodríguez } \\
\text { (2019) }\end{array}$ & & $\mathrm{X}$ & $\mathrm{X}$ & & Mixed & $\begin{array}{l}\text { Questionnaire on } \\
\text { communicative } \\
\text { competence }\end{array}$ \\
\hline 8 & Ravelo (2018) & & $\mathrm{X}$ & $\mathrm{X}$ & & Qualitative & Research Articles \\
\hline 9 & Zeinali (2017) & $\mathrm{X}$ & & $\mathrm{X}$ & & Qualitative & Research Articles \\
\hline 10 & Huarancca (2018) & $\mathrm{X}$ & $X$ & & $\mathrm{X}$ & Quantitative & $\begin{array}{l}\text { Observation, } \\
\text { Observation sheet }\end{array}$ \\
\hline 11 & $\begin{array}{l}\text { Hernández, Herrera y } \\
\text { Mena (2019) }\end{array}$ & $X$ & $\mathrm{X}$ & & $\mathrm{X}$ & Quantitative & $\begin{array}{l}\text { Observation, } \\
\text { observation sheet }\end{array}$ \\
\hline 12 & García (2019) & & $\mathrm{X}$ & $X$ & & Qualitative & $\begin{array}{l}\text { Fragments of } \\
\text { "Cinderella" }\end{array}$ \\
\hline 13 & Torres ét al. (2018) & & $\mathrm{X}$ & $\mathrm{X}$ & & Qualitative & $\begin{array}{l}\text { Observation sheet } \\
\text { on language } \\
\text { comprehension } \\
\text { and expression }\end{array}$ \\
\hline 14 & Gonzales (2019) & & $\mathrm{X}$ & $\mathrm{X}$ & & Qualitative & $\begin{array}{l}\text { Interview guide on } \\
\text { communicative } \\
\text { competence }\end{array}$ \\
\hline 15 & $\begin{array}{l}\text { Jímenez, Aragón y } \\
\text { Albedin (2020) }\end{array}$ & $\mathrm{X}$ & $\mathrm{X}$ & & $\mathrm{X}$ & Quantitative & $\begin{array}{l}\text { Questionnaires on } \\
\text { puppets and } \\
\text { communication } \\
\text { skills }\end{array}$ \\
\hline 16 & Campos (2010) & $\mathrm{X}$ & & $\mathrm{X}$ & & Qualitative & $\begin{array}{l}\text { Observation sheet } \\
\text { for a visit to the } \\
\text { theater }\end{array}$ \\
\hline 17 & Pablo (2018) & $\mathrm{X}$ & $X$ & & $X$ & Quantitative & Observation sheet \\
\hline 18 & Zhang, Z. & & $X$ & $\mathrm{X}$ & & Qualitative & $\begin{array}{l}\text { Questionnaire on } \\
\text { communicative } \\
\text { competence }\end{array}$ \\
\hline 19 & Cebrían (2016) & $X$ & $X$ & & $\mathrm{X}$ & Quantitative & $\begin{array}{l}\text { Observation, } \\
\text { observation sheet }\end{array}$ \\
\hline 20 & Mármol, A. (2019) & $\mathrm{X}$ & & $\mathrm{X}$ & & Qualitative & $\begin{array}{l}\text { Interview, } \\
\text { interview guide }\end{array}$ \\
\hline & Total & 13 & 16 & 11 & 9 & & \\
\hline & $\%$ & 65 & 80 & 55 & 45 & & \\
\hline
\end{tabular}

Of the 20 documents analyzed, 65\% (13) address research related to the use of puppets, $80 \%$ (16) investigate communication skills. On the other hand, $45 \%$ (9) of the investigations worked on the puppets 
variable and the communicative competences variable, $20 \%$ (4) investigated only the puppet variable, $35 \%$ (7) investigated only communicative competences. 50\% (10) of the investigations were of a qualitative approach, $45 \%$ (9) were of a quantitative approach and 5\% (1) of a mixed approach; in the same way, in $40 \%$ (8) an observation sheet was used as an instrument, in $20 \%$ (4) a questionnaire, in $15 \%$ (3) research articles, another 15\% (3) a guide interview, in 5\% (1) a test and another 5\% (1) a fragment of Cinderella.

\section{Discussion}

After the results of the systematic review of the documents, it was possible to determine two categories: Puppets and communicative competence; also, subcategories such as: expression and understanding, carrying out the discussion that is detailed below.

Regarding the permanent use of puppets with children, which allows us to discover their poetics, outlined in different nuances in the experiences from the first years, where the word, the technique used and the individual or collective work matters a lot and had as a characteristic, the construction of a device that allows the staging to go beyond, since the puppeteer suggested to the audience that they make drawings or write about what is perceived (Girotti, 2020). Existing theories point out the magical power and special connection that occurs between the puppet and the children, and this facilitates learning; Thus, it seeks to provide answers to why puppets can be an educational instrument; especially in pre-school and early-school students (Zeinali, 2017).

The use of various puppets to motivate activities is important as a strategic didactic resource to develop communication skills; That is why teachers should use in a general way in storytelling, pictures, videos or dialogues to facilitate students to answer questions, establishing fluent communication and naturally overcoming inhibition; This resource should also be used by parents to improve inter-family relationships and thus increase communicative competence (Huarancca, 2018). Teachers use puppets quite frequently, especially to cognitively develop kindergarten and elementary school students; where they improvise with movements to the rhythm of music, a story or poem, reading or narrating; and this stimulates the development of creativity (Campos \& Jarrosay, 2010); however, there is still a long way to go for this strategy to fulfill the fundamental role within the children's educational context.

The importance of the mediating role of puppets and communication was reflected in the interest shown by the teachers of a school community in Spain where the game was used as a methodological strategy in which the puppets play a facilitating role in the teaching-learning process. learning in which communication was facilitated for the participation of children with freedom and without inhibitions (Cebrián, 2016). In addition, it was found that puppets as a didactic resource, provide teachers with a tool to develop materials without economic damage, for classroom work, with many benefits, and can be used throughout the development of learning activities; Likewise, when children carry out work in small groups, they learn to execute sequencing, verbalization, classification, information and to have self-confidence (Mármol, 2019).

Likewise, with respect to the communicative competence category, it was stated that the incorporation of intercultural behavioral communicative competence takes on significant relevance, since training would imply the development of an intercultural awareness, which avoids misinterpretations, as well as misunderstanding in communication (Tapia \& Beltrán, 2019). Therefore, if communication skills are developed from home and school at an early age, students will be able to understand and understand their surroundings (Santacruz \& Montenegro, 2017). However, despite the benefits of the use of puppets in the development of communication skills, it was found that in the Peruvian educational system, these skills had not been developed (Delgado, 2017), which would show that they have not been using the appropriate resources or the methodology in which the use of puppets is involved to develop these skills, which leads to the need to generalize the use of this material in the various activities of early childhood education.

Thus, Yesid \& Duarte (2020) also demonstrated, after the application of the Pisa Test in Colombia, about the communicative competences in students at a national and international level, that there were low levels during the school year with respect to the averages of the OECD. That is why it is necessary to highlight the importance of the role played by communicative competence in the educational field, with the development of learning activities and communication in a different way to achieve a proposed objective; Thus the teacher becomes a communicator par excellence, manifesting himself and being an example for others; Thus, they are reconceptualized as sociolinguistic, discursive and strategic competences (Ravelo, 2018).

The growth of the use of computer tools, took a boom in education, where technological devices, computer tools had easy access for a large sector of the population, who managed to use the various digital content on the network; Thus, the development of narrative and digital communication skills was increased, as a basic element from the first years of children's formation; that allows the development of the ability to 
understand, analyze and communicate, either orally or in writing in real settings such as the classroom, or virtual in the current health emergency (Martínez Diaz \& Rodríguez Hernández, 2020). In the same way, there are difficulties such as linguistic intercomprehension, which is the development of the communicative competence that speakers of different mother tongues have in seeking communication between them, an ability that manages to favor the preservation of effective relationships between members of different similar cultures; where, ICTs promoted the formation of areas for the relationship between the study of linguistic misunderstanding and the didactics of multilingualism (García-Fernández, 2019).

The development of communicative competence fulfills an important learning path to listen, understand a message, interpret a speech orally, speak confidently, be coherent, write a text, create a personal message; allowing the student to perform better in different social contexts, hence the use of puppets is important due to their immediate and mediate consequences to generate communication skills over time (Huarancca, 2018). Thus, communicative competence is presented in people in an implicit and explicit way during academic training, where the development of timely competence is achieved for the construction of effective messages that are directed to groups of people in different media and codes; that allows the teacher to handle situations that increase competence from his teaching role and as a communication professional and generate construction of knowledge for learning (Olmos, 2020).

The students present a meager stimulation to develop communicative competence, limited demonstration of initiatives for the contribution of ideas, difficulties in the use of non-verbal and paraverbal resources for the participation of some contribution referred to topics covered, without delving into the content of the development of the works, lacking appropriate strategies that evidence the didactic procedure of communicative competence, hindering the obtaining of significant changes in the development of learning (Pablo, 2018). One of the great difficulties for a good development in organizations is the development of communication skills, which is considered as an intangible asset; which is linked to the organizational climate, motivation, change, social responsibility, among others; where interpersonal communication is important, both internally and externally, as well as face-to-face or virtual communication, as part of personal success (Hernández et al., 2019).

The acquisition of tools for interaction with the environment in which they live, takes place in the early years, where children manage to develop communicative skills receiving encouragement from their peers, family and teachers who contribute to the development of personality, in the As models for the increase of lexical-semantic, syntactic and pragmatic language communication skills and abilities are the important means for teaching and learning, the increase of new words, which also implies the support of the family, which is the children's first educator (Torres et al., 2018).

However, it should be noted that communicative competences will be affected by cultural and regional mediation, language identity and linguistic transculturation, which on more than one occasion will affect communicative relationships due to lexical alteration or the use of regional synonyms and that will affect the dynamics of language and that a living language is obviously normal (González, 2019).

On the other hand, the importance of the communication skills of people in general and of future teachers in particular lies in the skills that teachers must show so that the communication performance of students and families reaches an optimal level in their relationships with others. (Jiménes-Fontana et al., 2020). Thus, to develop communicative skills with low or high levels, the learners write group scripts, that is, they communicate and collaborate with each other, not only in the process of preparing texts but also when they use qualitative techniques when conducting interviews to collect data, of the transcription and when analyzing the text; This happens when students do not want a face-to-face interaction, which is the most important in an intercultural communicative competence (Zhang, 2020).

In the same way, with respect to the student category, in the school education of children belonging to a marginal urban area, they lack economic income and basic services, dysfunctional families, there is neglect and ignorance of parents about development of communication skills, where they expose their children to other social environments that do not facilitate their learning and are left in the care of siblings or other family members, which does not allow them an adequate development of expression and understanding (Huarancca, 2018).

\section{Conclusion}

Among the conclusions, there is: The use of puppets through the years for entertainment, has been transferred as a pedagogical tool, allowing the child to fix the attention, motivate him, interact with other children; Thus, teachers use puppets in the classroom for the cognitive development of children and improvise with movements to the rhythm of music, story or poem, reading or narrating; Teachers also use puppets through playful activities according to the theme developed; This stimulates the development of creativity and communication skills. 
The levels of development of communication skills have increased, which is evidenced in the PISA tests in the different developing countries of the world, being favored with the use of a technological tool such as tics, which allows people to interact in a different way. fluent and effective way, even if they come from different cultures; Likewise, developing communicative competence implies understanding a message, interpreting a speech orally, speaking safely, being coherent, writing a text, creating a personal message; and allows the construction of effective messages that are directed to groups of people in different media and codes, it is also a fundamental means to teach and learn in the increase of new words.

The students who comprise the analysis unit of the study, belonging to a public educational institution, come from low-income areas, which require the use of methodological strategies such as puppets for the optimization of communicative competences, because, said children have difficulties in their expression and understanding.

\section{References}

1. Campos Cuevas, I., \& Jarrosay Quiala, E. (2010). Elretablo de Títeres y su influencia en la educación y la creatividad de los niños de edad preescolar. EduSol, 10(30), 45-51.

2. Cebrián, B. (2016). El títere y su valor educativo. Análisis de su influencia en Titirimundi, Festival Internacional de Títeres de Segovia. In Universidad de Valladolid.

3. Delgado, M. (2017). Las historietas y el desarrollo de las competencias comunicativas en niñlos de educación primaria de la institución educativa Fe y Alegria $N^{\circ} 64$ de Tingo María-2017.

4. García-Fernández, J. (2019). The romance linguistic system in the developmentof communicative competence. La Colmena, 103, 9-28. https://doi.org/10.36677/lacolmena.v0i103.12032

5. Girotti, B. (2020). Puppets, writing and drawing: Javier Villafañe and the children's voices collection. Telar, 24, 81-97.

6. Gómez, J. (2004). La recopilación documental: Para qué y cómo documentarse en Ciencias de la Información Documental. Metodologías de Investigación En Información y Documentación, January 2004, 33-70. https://dialnet.unirioja.es/servlet/extart?codigo=1224894

7. González, F. (2019). El desarrollo de la competencia comunicativa intercultural: formación de identidades en un contexto colombiano. Revista de Didáctica Español Lengua Extranjera, 28, 1-26. http://www.redalyc.org/articulo.oa?id=92157659001\%0A

8. Hernández, V., Herrera, K. L., \& Mena, M. (2019). Socio-psychological training to improve interpersonal communicative competence: study of a case.Comuni@cción: Revista de Investigación En Comunicación y Desarrollo, 10(1), 5-20. https://doi.org/10.33595/2226-1478.10.1.326

9. Huarancca Tello, K. (2018). Aplicación de los títeres como recurso didáctico para fortalecer las habilidades comunicativas en los estudiantes de 5 años de la I.E.I. "Virgen de Lourdes" de Villa María del Triunfo - 2016. Universidad César Vallejo.

10. Jiménes-Fontana, R., Aragón, L., \& Albendín, G. (2020). Análisis de la incidencia de talleres formativos en el desarrollo de competencias comunicativas en futuros docentes y ambientólogos. Revista Eureka Sobre Enseñanza y Divulgación de Las Ciencias, 17(3), 3202-3218.

11. Mármol, R. (2019). Teatro de títeres como estrategia para potenciar la atención de niños de 5 años de la Escuela de Educación Básica Isabel Herrera de Velasquez. Revista Conrado, 15(70), 370-375.

12. Martínez Diaz, L. Y., \& Rodríguez Hernández, A. A. (2020). The booktrailer as a didactic strategy for the development of communicative, narrative and digital competences. Revista Boletín Redipe, 9(6), 168-182. https://doi.org/10.36260/rbr.v9i6.1010

13. Olmos, R. G. (2020). Communicative competence in venezuelan social communication professors. Educere, 24(79), 571-587.

14. Pablo, Z. V. (2018). Jugando con los títeres mejoro mis habilidades comunicativas Proyecto de innovación para los niños de 5 años de una I.E.I. del distrito de San Martín de Porres.

15. Ravelo, X. C. (2018). La competencia comunicativa, premisa para la imagen social del maestro. EduSol, 18(62), 161-166. file:///C:/Users/Lina Yanac/Downloads/DialnetLaCompetenciaComunicativaPremisaParaLaImagenSocial-6303480 (4).pdf

16. Santacruz, A., \& Montenegro, H. (2017). The strategy of the debate in oral communication skills in children of the Initial Education Institution $\mathrm{N}^{\circ} 318$ Jean Piaget, Ucayali. Apuntes de Ciencia \& Sociedad, 07(01), 27-31. https://doi.org/10.18259/acs.2017005

17. Tapia-Vidal, A., \& Beltrán-Véliz, J. (2019). Behavorial communication competencies. Revista Facultad de Medicina, 67(2), 357-358. https://doi.org/10.15446/revfacmed.v67n2.74050

18. Torres, Y., Madrigal, M., Delgado, H., Shauri, J., Galarza, A., \& Gallegos, G. (2018). El desarrollo de las competencias comunicativas en educación parvularia a través del juego. Didáctica y 
Educación., 9, 1-10.

19. Vera, O. (2009). Artículos de Revisión. Revista Médica La Paz, 15(1), $63-69$. https://doi.org/10.1055/s-0037-1606585

20. Yesid, H., \& Duarte, N. (2020). La emisora escolar: estrategia didáctica para desarrollar competencias comunicativas de lectura y escritura en estudiantes de básica primaria. Revista Papeles, 12(23), 98-111.

21. Zeinali, H. (2017). Los títeres como herramienta educativa para niños de infantil y primaria.

22. Zhang, Z. (2020). Técnicas de investigación cualitativa como instrumentos de enseñanzaaprendizaje de la competencia comunicativa e intercultural de estudiantes sinohablantes de ELE. Revista de Didáctica Español Lengua Extranjera, 30. 